\title{
RESEARCH
}

\section{Incidental Carcinoma Gallbladder Cases in Routine Cholecystectomy}

\author{
Alam Fahad \\ Department of Pathology, National Medical College, Birgunj, Nepal.
}

Date of Submission: Feb 15, 2019

Received in Revised Form: March 15, 2019

Date of Acceptance: April 22, 2019

Date of Publishing: July 30, 2019

\begin{abstract}
Background:

Gallstone is a very common gastrointestinal disorder. It is known to produce histopathological changes in the gallbladder. It is also one of the predisposing factors for the development of cancer of gallbladder. Most of the carcinoma of gallbladder is diagnosed as incidental finding among patients undergoing cholecystectomy. This study was carried out to find out cases of incidental carcinoma gallbladder in patients operated for cholecystitis.
\end{abstract}

\section{Methods:}

This is a hospital based descriptive study conducted in Department of Pathology at Nepalgunj Medical College Teaching Hospital, Kohalpur from April 2015 to March 2016. Total of 260 surgical specimens of gallbladder were included in the study.

\section{Results:}

In this study, there were 5 cases of incidental carcinoma gallbladder (1.92\%).In the carcinoma patients, the mean age was 56 years with M: F ratio 1:4. Adenocarcinoma of the gallbladder was the most common malignancy of the gallbladder.

\section{Conclusion:}

Histopathology is a gold standard method for detection of carcinoma of gallbladder, as it is superior to clinical and radiological examination.
Routine histopathological study of all cholecystectomy specimens are suggested as it helps in diagnosing occult gallbladder carcinomas.

Key words: Carcinoma Gallbladder, Cholecystectomy, Cholecystitis, Histopathology, Incidental.

*Corresponding Author: Dr.FahadAlam, Department of Pathology, National Medical College, Birgunj,Nepal.

Email: fahadalam14@gmail.com

\section{INTRODUCTION}

The gallbladder is a pear shaped sac attached to the posteroinferior aspect of the right hepatic lobe. In the adult, it measures up to $10 \mathrm{~cm}$ in length and 3 to $4 \mathrm{~cm}$ in width. The gallbladder is divided into the following regions: fundus, body, and neck. The portion of the body that joins the neck is referred to as the infundibulum; sometimes there is a small bulge in this portion, known as Hartmann pouch.

The gallbladder via the cystic duct joins with the common hepatic duct to form the common bile duct that empties into the duodenum. The primary function of the gallbladder is to concentrate and store hepatic bile and deliver bile into the duodenum in response to a meal. ${ }^{2}$

Gallbladder cancer is a disease of the elderly; it affects patients in their 70 s, with a female to male 
ratio 5:1. Gallbladder carcinoma is an aggressive malignancy, with most large series reporting 5 year survival rates of $5-15 \%$. In $25 \%$ of the patients the cancer is localized to the gallbladder wall, in $35 \%$ it is spread beyond the wall to adjuvant soft tissue, and in $45 \%$ distant metastases occur.

Cholecystectomy is the surgical removal of the gallbladder. Identification of gallbladder lesions requires proper investigations including plain abdominal x-ray, transabdominal ultrasonography, radioisotope scans, and proper histological examination. The value of histological examination is well explained in patients with gallbladder lesions where adjuvant treatment is dependent upon grade, severity and extent of invasion of disease. Many patients may be suspected of having a malignancy on preoperative assessment; in these cases histological examination may aid to rule out suspicion.

Cholecystectomy specimens are one of the frequently encountered specimens in routine work in the pathology department. Meticulous macroscopic evaluation and proper sampling constitute the first steps of histopathological diagnosis.

Cholecystectomy specimen may reveal an unexpected gallbladder carcinoma. It is a rare malignancy with overall poor prognosis especially if diagnosed late in the course of the disease. Hence, the histopathological examination of every cholecystectomy specimen is of utmost importance. ${ }^{4}$

\section{METHODS AND MATERIALS}

This is a hospital based descriptive study conducted in Department of Pathology at Nepalgunj Medical College Teaching Hospital, Kohalpur from April 2015 to March 2016. This study was carried out in 271 cholecystectomy specimens. Specimens not accompanied by relevant clinical details, specimens not sent in proper fixatives and specimens with a clinical diagnosis of carcinoma gallbladder were excluded from the study. Due to chemical autolysis (6 specimens) and 5 cases due to lack of relevant clinical details were excluded. Therefore total sample size was 260.The data were tabulated and analyzed using Statistical Package for Social Sciences (SPSS) version 21.0

\section{RESULTS}

A total of 271 cholecystectomy specimens were received in our department. Eleven cholecystectomy specimens were excluded either due to autolytic changes or inadequate clinical details. Most of the cases diagnosed histopathologically were acute or chronic calculus cholecystitis (94.6\%), 7 patients had dysplasia $(2.7 \%), 1$ patient each had adenoma and hydrops gallbladder $(0.4 \%)$. There were 5 cases of incidental finding of carcinoma gallbladder $(1.92 \%)$. Six patients were operated for gallbladder polyp but on gross examinations no polyps were identified in any of the six specimens. Among chronic cholecystitis, its variants included follicular cholecystitis, xanthogranulomatous cholecystitis and follicular cholecystitis in 5 cases each.

None of the cases were suspected pre or intraoperatively to have gallbladder carcinoma. Out of the 5 cases of GB carcinoma, 4 were adenocarcinoma and 1 was undifferentiated carcinoma. All 5 patients had associated stones and were non vegetarians.

The age ranged from 16 to 77 years with a mean age of 39.58 years. Most patients were in the age group 31 to 40 years $(30 \%)$ followed by 21 to 30 years $(25.8 \%)$ and 41 to 50 years $(20.8 \%)$. Male patients were 37 and 223 were females. There was a female preponderance in this study with $\mathrm{M}$ : F ratio 1:6.

A clinical diagnosis of chronic cholecystitis was made in $93.8 \%$ of the cases which increased to 95\% after USG. Most of the cholecystectomies were performed for calculus cholecystitis (95\%). The histological diagnosis were narrowed down into 5 diagnosis for statistical purposes which included adenoma $(0.4 \%)$, carcinoma $(1.9 \%)$, chronic cholecystitis (94.6\%), dysplasia of gallbladder $(2.7 \%)$ and hydrops gallbladder $(0.4 \%)$.

Gallbladder cancer was detected in $5(1.92 \%)$ cases and was more common in females $(\mathrm{M}$ : $\mathrm{F}$ ratio 1:4). The mean age of occurrence was 56 years. Majority of the patients who were diagnosed as carcinoma presented with abdominal pain, dyspepsia, weight loss, anorexia, nausea, malaise, pruritus and vomiting. Generally patients with carcinoma have delayed onset of symptoms. 
Table 1: Clinicopathological Features of Carcinoma Gallbladder

\begin{tabular}{|c|c|c|c|c|c|}
\hline $\begin{array}{c}\text { Age } \\
\text { (Years) }\end{array}$ & Sex & USG findings & $\begin{array}{c}\text { Gross } \\
\text { findings }\end{array}$ & Type of tumor & $\begin{array}{c}\text { Stage } \\
\text { (TNM) }\end{array}$ \\
\hline 66 & $\mathrm{~F}$ & $\begin{array}{c}\text { Calculus } \\
\text { cholecystitis }\end{array}$ & $\begin{array}{c}\text { No significant } \\
\text { findings }\end{array}$ & $\begin{array}{c}\text { Well differentiated } \\
\text { adenocarcinoma }\end{array}$ & T2NxMx \\
\hline 55 & $\mathrm{~F}$ & $\begin{array}{c}\text { Calculus } \\
\text { cholecystitis }\end{array}$ & $\begin{array}{c}\text { No significant } \\
\text { findings }\end{array}$ & $\begin{array}{c}\text { Poorly differentiated } \\
\text { adenocarcinoma }\end{array}$ & $\mathrm{T} 1 \mathrm{bNxMx}$ \\
\hline 40 & $\mathrm{~F}$ & $\begin{array}{c}\text { Calculus } \\
\text { cholecystitis }\end{array}$ & $\begin{array}{c}\text { No significant } \\
\text { findings }\end{array}$ & $\begin{array}{c}\text { Well differentiated } \\
\text { adenocarcinoma }\end{array}$ & $\mathrm{T} 2 \mathrm{NxMx}$ \\
\hline 77 & $\mathrm{~F}$ & $\begin{array}{c}\text { Calculus } \\
\text { cholecystitis }\end{array}$ & $\begin{array}{c}\text { Polypoidal } \\
\text { projection in } \\
\text { the mucosa }\end{array}$ & $\begin{array}{c}\text { Well differentiated } \\
\text { adenocarcinoma }\end{array}$ & $\mathrm{T} 2 \mathrm{NxMx}$ \\
\hline $\mathrm{M}$ & $\begin{array}{c}\text { Calculus } \\
\text { cholecystitis }\end{array}$ & Adhesions & $\begin{array}{c}\text { Undifferentiated } \\
\text { carcinoma }\end{array}$ & $\mathrm{T} 3 \mathrm{NxMx}$ \\
\hline
\end{tabular}

\section{DISCUSSION}

Among patients who were diagnosed as carcinoma gallbladder, the mean age was 56 years with $\mathrm{M}: \mathrm{F}$ ratio $1: 4$. This finding is similar to the retrospective analysis of 52 patients in which the mean age of gallbladder cancer was 51.5 years and more than 80 percent of cases were females. ${ }^{5}$

Similar finding had been reported in several studies from Indian subcontinent which showed gallbladder cancer affects predominantly female in their fourth and fifth decade of life..$^{6-9}$ However, studies from other part of the world has shown that gallbladder cancer was predominant in females with peak incidence in sixth and seventh decade of life..$^{10-15}$ The reason, for gallbladder cancer developing at a younger age in Indian subcontinent population including Nepal, could be because, gallstones develop at a younger age in Indian subcontinent population than western population. ${ }^{6}$ and gallstone is important risk factor for development of cancer. This age difference of gallbladder cancer patients from western population might be over-estimated, as the life expectancy in Nepal is low (male 68 and female 71 years $).{ }^{16}$

Gallstones appear to be the most important risk factor, being reported in $98 \%$ cases of gallbladder cancer. ${ }^{17}$ Though gallstones are very often implicated with gallbladder carcinoma, other factors tend to increase the risk include porcelain gallbladder, chronic infection with Salmonella typhi, carcinogen exposure (eg. miners exposed to radon), and abnormal pancreatobiliary junction. ${ }^{18}$ Most of the cases of carcinoma GB are diagnosed at advanced stage and have a poor prognosis having 5 year survival rate of $<5 \%$. When detected at early stages prognosis may improve significantly up to $90-100 \%$ five years survival rate. $^{19,20}$
The incidence of incidental GB carcinoma in routine post-cholecystectomy cases was $1.92 \%$. Amanullah et al $(1.8 \%),{ }^{21}$ Shrestha $\mathrm{R}$ et al $(1.4 \%)^{22}$ and Ghimire $\mathrm{P}$ et al $(1.28 \%)^{23}$ have found the incidence similar to ours whereas Zhang WJ et $\mathrm{al}^{24}$ has shown it occurrence as low as $0.19 \%$ and Naqvi et al has found its occurrence as high as $5.9 \% .{ }^{25}$ Autopsy studies indicate that only $1-4 \%$ of patient with cholelithiasis develop cancer compared to $<0.2 \%$ of those not containing stones. ${ }^{26}$ Most of the studies listed in table no. 2 show similar findings.

Table 2: List of Various Studies Showing Incidence of Incidental Carcinoma Gallbladder. ${ }^{27-29}$

\begin{tabular}{|c|c|c|c|c|c|c|}
\hline Studies & Vear & Place & $\begin{array}{c}\text { Sample } \\
\text { size }\end{array}$ & M:F & $\begin{array}{c}\text { Mean } \\
\text { age(vears) }\end{array}$ & $\begin{array}{c}\text { Incidence of } \\
\text { Ca GB }\end{array}$ \\
\hline $\begin{array}{c}\text { Daphna et } \\
\text { al }\end{array}$ & - & Israel & 1697 & $1: 5$ & 70 & $0.3 \%$ \\
\hline $\begin{array}{c}\text { Khoo JJ } \\
\text { \&Nurul } \\
\text { AM }\end{array}$ & $\begin{array}{c}2000- \\
2005\end{array}$ & Malaysia & 1122 & $1: 2$ & 56.7 & $0.62 \%$ \\
\hline $\begin{array}{c}\text { Mittal R et } \\
\text { al }\end{array}$ & $\begin{array}{c}1998- \\
2007\end{array}$ & India & 1305 & $1: 5.5$ & 56.2 & $0.99 \%$ \\
\hline $\begin{array}{c}\text { Zhang WJ } \\
\text { et al }\end{array}$ & $\begin{array}{c}1999- \\
2007\end{array}$ & China & 10,466 & $1: 4$ & 65.7 & $0.19 \%$ \\
\hline $\begin{array}{c}\text { Amanullah } \\
\text { et al }\end{array}$ & $\begin{array}{c}2000- \\
2002\end{array}$ & India & 428 & $1: 7$ & 47 & $1.87 \%$ \\
\hline $\begin{array}{c}\text { Shrestha R } \\
\text { et al }\end{array}$ & $\begin{array}{c}2003- \\
2007\end{array}$ & Nepal & 570 & $1: 3.5$ & 53.56 & $1.4 \%$ \\
\hline Naqvi et al & $\begin{array}{c}1985- \\
2004\end{array}$ & Pakistan & 1109 & $1: 4.4$ & - & $5.9 \%$ \\
\hline $\begin{array}{c}\text { Ghimire P } \\
\text { et al }\end{array}$ & $\begin{array}{c}1998- \\
2009\end{array}$ & Nepal & 783 & $1: 2.3$ & 68.3 & $1.28 \%$ \\
\hline $\begin{array}{c}\text { Present } \\
\text { study }\end{array}$ & $\begin{array}{c}2015- \\
2016\end{array}$ & Nepal & 260 & $1: 4$ & 56 & $1.92 \%$ \\
\hline
\end{tabular}

\section{CONCLUSION}

The histopathological spectrum of gallbladder disease after cholecystectomy was found to be quite diverse. The most common histopathological diagnosis in gallstone disease was chronic cholecystitis, which was associated with a variety of mucosal alterations and lesions like cholesterosis, metaplasia, dysplasia and adenomyoma. Increased rate of carcinomas was also seen in our study, which reinforces the importance of histopathological examination in all routine cholecystectomy specimens.

It is a standard practice to perform routine histopathological examinations for all cholecystectomy specimens. Various studies including the working reporting of Royal College of Pathologists have recommended for this routine standard practice.

\section{REFERENCES}

1. Rosai J, editor. Rosai and Ackerman's Surgical Pathology. 10th ed. Edinburgh: Elsevier; 2012. vol 1 p. 981,987-88.

2. Schwartz SI. Gall bladder and extrahepatic biliary system. In: Brunicaardi FC, Anderson DK, Billiar TR, Dunn DL, 
Hunter JG, Pollock RE, editors. Principles of surgery. 8th ed. New York: MC GrawHill; 2005. p. 1194-204.

3. Tran H Giang, Tran TB Ngoc and Lewis A. Hassell. Carcinoma involving the gallbladder: a retrospective review of 23 cases - pitfalls in diagnosis of gallbladder carcinoma. Diagn Pathol. 2012; 7:10.

4. Beal JM. Historical perspective of gall stone diseases. Surg Gynecol Obstet. 1984; 158(2):181-9.

5. Li Y, Zhang J, Ma H. Chronic inflammation and gallbladder cancer. Cancer let. 2014; 345(2):242-8.

6. Pandey M. Risk factors for gallbladder cancer: a reappraisal. Eur J Cancer Prev. 2003; 12(1):15-24.

7. Kumar JR, Tewari M, Rai A, Sinha R, Mohapatra SC, Shukla HS. An objective assessment of demography of gallbladder cancer. J Surg Oncol. 2006; 93(8):610-4.

8. Alvi AR, Siddiqui NA, Zafar H. Risk factors of gallbladder cancer in Karachi-a case-control study. World J Surg Oncol. 2011;9(1):164.

9. Panda D, Sharma A, Shukla NK, Jaiswal R, Dwivedi S, Raina V et al. Gall bladder cancer and the role of dietary and lifestyle factors: a case-control study in a north Indian population. Eur $\mathrm{J}$ Cancer Prev. 2013; 22(5):431-7.

10. Arminski TC. Primary carcinoma of the gallbladder. A collective review with the addition of twenty five cases from the grace hospital, Detroit, Michigan. Cancer. 1949; 2(3):379-98.

11. Nervi F, Duarte I, Gómez G, Rodríguez G, Pino GD, Ferrerio O, et al. Frequency of gallbladder cancer in Chile, a high risk area. Int J Cancer. 1988; 41(5):657-60.

12. Kato K, Akai S, Tominaga S, Kato I. A case control study of biliary tract cancer in Niigata Prefecture, Japan. Jpn J Cancer Res. 1989; 80(10):932-8.

13. Zatonski WA, Przewozniak K, Lowenfels AB, Boyle P, Maisonneuve P, de Mesquita $\mathrm{HB}$, et al. Epidemiologic aspects of gallbladder cancer: a case-control study of the search program of the international agency for research on cancer. Natl Cancer Inst. 1997; 89(15):1132-8.
14. Scott TE, Carroll M, Cogliano FD, Smith $\mathrm{BF}$, Lamorte WW. A case-control assessment of risk factors for gallbladder carcinoma. Dig Dis Sci. 1999; 44(8):1 619-25.

15. Lazcano Ponce EC, Miquel JF, Muñoz N, Herrero R, Ferrecio C, Wistuba II, et al. Epidemiology and molecular pathology of gallbladder cancer. CA Cancer J Clin. 2001; 51(6):349-64

16. World health organization. Nepal, statistic: life expectancy birth $\mathrm{f} / \mathrm{m}$ (years 2015) [Online]. Available from: URL: http://www.who.int/countries/npl/en/

17. Al-Hadeedi SY, Moorehead RJ, Leaper DJ, Wong J. Carcinoma of the gallbladder: a diagnostic challenge. J R Coll Surg Edinb. 1991; 36(3):174-7.

18. WhangEe, Zinner MJ. Cancer of the gallbladder and the bile ducts. In: ZinnerMj, Ashley Sw, editors. Maingot's abdominal operations. 11 th ed. New York: McGraw Hill: 2007. p. 921-35.

19. Eric Ch, Lau Wy. Gallbladder Cancer: a comprehensive review. Surgeon 2008; 6(2)10-9.

20. Misra MC, Guleria S. Management of cancer gallbladder found as a surprise on a resected gallbladder specimen. J Surg Oncol. 2006; 93(8):690-8.

21. Amanullah MK, Rizwan AK, Shahid S, Veena M. Occult carcinoma of gallbladder: Incidence and role of simple cholecystectomy. JK- Practitioner. 2007; 14(1):22-3.

22. Shrestha R, Tiwari M, Ranabhat SK, Aryal G, Rauniyar SK, Shrestha HG.Incidental gallbladder carcinoma: value of routine histological examination of cholecystectomy specimens. Nepal Med Coll J. 2010; 12(2):90-4.

23. Ghimire P, Yogi N, Shrestha BB. Incidence of incidental carcinoma gall bladder in cases of routine cholecystectomy. Kathmandu Univ Med J. 2012; 9(2):3-6.

24. Zhang WJ, Xu GF, Zou XP, Wang WB, Yu $\mathrm{JC}, \mathrm{Wu} \mathrm{GZ}$, et al. Incidental gallbladder carcinoma diagnosed during or after laparoscopic cholecystectomy. World J Surg. 2009; 33(12):2651-6. 
25. Naqvi SQ, Mangi IH, Dahri FJ, Khaskheli QA, Akhund AA. Frequency of carcinoma of gall bladder in patients with cholelithiasis. Gomal J Med Sci.2005;3(2):

26. Silk YN, Douglass HO, Nava HR, Driscoll DL, Tartarian GA. Carcinoma of the gallbladder. The Roswell Park experience. Ann Surg. 1989; 210(6):751.

27. Daphna W, Mehrdad H, Noa BJ, Sandbanand AH. Incidental finding of gallbladder carcinoma. Israel Med Assoc J. 2002; 4:334-6.

28. Khoo JJ, Misron NA. A clinicopathological study of nine cases of gallbladder carcinoma in 1122 cholecystectomies in Johor, Malaysia. Malaysian J Pathol. 2008; 30(1):21-6.

29. Mittal R, Jesudasan MR, Nayak S. Selective histopathology in cholecystectomy for gallbladder disease. Indian $\mathrm{J}$ Gastroenterol. 2010;29(1):32-6. 